\title{
State of the Art Treatment of Produced Water
}

\author{
Rangarajan T. Duraisamy, Ali Heydari Beni and Amr Henni
}

Additional information is available at the end of the chapter

http://dx.doi.org/10.5772/53478

\section{Introduction}

Produced water is water trapped during subsurface formations which is brought to the surface along with oil or gas. It contributes the largest volume of waste stream associated with oil and gas production. Globally, 77 billion bbl of water are produced per annum. The conventional methods to handle waste stream are reinjection into the well, direct discharge or reuse in case of thermal loop. Out of these, the most efficient way of handling produced water is to re-inject it into disposal wells. The disposal cost, which includes transportation cost, capital cost and infrastructure maintenance cost, may be as much as $\$ 4.00 / \mathrm{bbl}$. On the other hand, many oil producing regions (West Texas, Middle East and the Central Asian Republics) have scarcity of potable water. An affordable water treatment process could convert produced water into an asset. The harmful effects of produced water and the depletion of usable water resources act as a driving force for the treatment of produced water.

Produced water contains soluble and insoluble organic compounds, dissolved solids, production chemicals (corrosion inhibitors, surfactants etc.) and solid particles due to leaching of rocks and corrosion of pipelines. The methods available for treating produced water are physical, chemical, biological and membrane treatment processes.

Stringent water quality parameters can be achieved efficiently through membrane processes. The most important advantages of using membrane processes are the ease of operation and little or no requirement of chemicals. Based on pore size, the membrane processes could be classified into Microfiltration (MF), Ultrafiltration (UF) and Nanofiltration (NF). The membranes are also classified as organic, inorganic and composite membranes. The primary disadvantage of using membranes is fouling. Irreversible and reversible foulings occur while treating produced water. The usage of appropriate pre-treatment process reduces the membrane fouling to a greater extent. Commercial treatment methods based on reverse osmosis and ion exchange processes are also discussed. 


\section{Characteristics of produced water}

The physical and chemical properties of produced water depend on the geographic location of the field, the geological formation with which the produced water has been in contact for thousands of years, and the type of hydrocarbon product being produced.

The main constituents of produced water are as follows:

- dissolved and dispersed oil compounds

- dissolved formation minerals

- $\quad$ production chemical compounds

- production solids (formation, corrosion, scale, bacteria, waxes, and asphaltenes)

- dissolved gases

Produced waters discharged from gas/condensate platforms are about 10 times more toxic than the produced waters discharged from oil wells, but, the volumes from gas production are much lower; hence the total impact may be less.

\subsection{Constituents in produced water}

1. Dispersed oil: Oil is an important contaminant in produced water since it can create potentially toxic effects near the discharge point. It can significantly contribute to Biological Oxygen Demand (BOD) and hence affects the aquatic or marine ecosystem. Usually the size of dispersed oil droplets would be 4-6 microns, but it may vary from 230 microns. The current treatment systems could recover oil droplets of size up-to 10 microns.

2. Dissolved Organic Compounds: They include organic acids, polycyclic aromatic hydrocarbons (PAHs), phenols and volatiles. Volatile hydrocarbons can occur naturally in produced water. Concentrations of these compounds are usually higher in produced water from gas-condensate-producing platforms than in produced water from oilproducing platforms.

3. Treatment Chemicals: They include biocides, reverse emulsion breakers, and corrosion inhibitors. Corrosion inhibitors can form stable emulsions. Some chemicals are highly toxic even at low concentrations such as $0.1 \mathrm{ppm}$.

4. Produced Solids: They consist of precipitated solids (scales), sand and silt, carbonates, clays, corrosion products and other suspended solids produced from the formation and from well bore operations.

5. Bacteria: Anaerobic bacteria present in produced water may lead to corrosion.

6. Metals: Zinc, Lead, Manganese, Iron and Barium are the metals usually present in produced water. They are in general less toxic when compared to organic constituents. But they may precipitate to form undesired solids which hinder the treatment processes.

An example of key parameters of produced water is listed below in Table 1. 


\section{Produced water management ${ }^{[1]}$}

a. Injection into oil wells: The produced water is injected into the same oil well from where it is obtained or transported to the discharge well at another location. The cost varies from $\$ 0.70$ to $\$ 4.00$.

b. Direct discharge: The produced water is discharged directly as per the regulation norms. The cost varies from $\$ 0.03$ to $\$ 0.05$.

c. Reuse in oil and gas operation: The produced water could be treated and used in the oil and gas processing industries. The cost varies from $\$ 0.04$ to $\$ 0.07$.

d. Consumed in beneficial use: Treating produced water to convert it into an asset. The cost varies from $\$ 0.25$ to $\$ 2.00$.

\begin{tabular}{|l|l|l|}
\hline Parameter & Natural Gas Produced Water & Oil field Produced Water \\
\hline Oil/grease $(\mathrm{ppm})$ & 40 & 560 \\
\hline pH & $4.4-7.0$ & $4.3-10$ \\
\hline TSS $(\mathrm{ppm})$ & 5500 & 1000 \\
\hline TDS $(\mathrm{ppm})$ & 360,000 & 6554 \\
\hline TOC $(\mathrm{ppm})$ & $67-38,000$ & 1500 \\
\hline COD $(\mathrm{ppm})$ & 120,000 & 1220 \\
\hline Density $\left(\mathrm{kg} / \mathrm{m}^{3}\right)$ & 1020 & 1140 \\
\hline Arsenic $(\mathrm{ppm})$ & $0.005-151$ & $0.005-0.3$ \\
\hline Lead $(\mathrm{ppm})$ & $0.2-10.2$ & $0.008-8.8$ \\
\hline Chromium $(\mathrm{ppm})$ & 0.03 & $0.02-1.1$ \\
\hline Mercury $(\mathrm{ppm})$ & -- & $0.001-0.002$ \\
\hline Oil droplet size $(\mu \mathrm{mm})$ & 2 to 30 & \\
\hline
\end{tabular}

Table 1. Key parameters of importance in produced water treatments ${ }^{[1]}$

\section{Treatment methods}

\subsection{Physical treatment}

\subsubsection{Physical adsorption}

Activated carbon, organoclay, copolymers, zeolite, resins are widely used to treat produced water. The combination of activated carbon and organoclays proved to be more efficient in removing total petroleum hydrocarbons (TPH). ${ }^{[2]}$ Copolymers reduce the oil content up to $85 \%{ }^{[3]}$ Zeolites are efficient in removing BTEX compounds. ${ }^{[4]} \mathrm{A}$ multi-stage adsorption and separation system was developed, for example, by EARTH Canada Corporation to recover dispersed oil droplets in water, whose size is greater than 2 microns..$^{[5]}$

\subsubsection{Sand filters}

They are generally used to remove metals from produced water. Process requires series of pre-treatment steps such as $\mathrm{pH}$ adjustment, an aeration unit and a solid separation unit. The removal efficiency is as high as $90 \% .^{[6]}$ 


\subsubsection{Cyclones}

A compact floatation unit (CFU) could remove dispersed oil from $50 \%$ to $70 \%$ using a centrifugal force. ${ }^{[7] T h e}$ major drawback of using a cyclone is its low efficiency and inability to remove dissolved components. ${ }^{[8]}$

\subsubsection{Evaporation}

Evaporation does not require chemical treatment which eliminates the risk of secondary sludge handling. It also does not require highly skilled labor. On the other hand, the requirement of energy is very high which increases the operating cost. The energy consumption could be brought down by reusing hot vapor to heat the fresh feed. ${ }^{[9]}$

\subsubsection{Dissolved air precipitation (DAP)}

In this process, water at $500 \mathrm{kPa}$ (for example) is saturated with air in a packed column separator. The pressure is released into the water column which causes the formation of air bubbles. It induces the flotation of aliphatic and aromatic hydrocarbons, and removes the aliphatic compounds more efficiently than aromatic compounds. ${ }^{10]}$

\subsubsection{C-TOUR}

It is a patented technology that uses liquid condensate to extract dissolved components from produced water. In field trials, the removal efficiency of dispersed oil was found to be $70 \% \cdot{ }^{[7]}$

\subsubsection{Freeze-thaw/evaporation}

This technology uses the principle of solubility dependency on temperature. When the solution is cooled below the freezing point of the solvent but not below the depressed freezing point of the solution, relatively pure crystals of solvent and unfrozen concentrated solutions are obtained. If we couple this process with conventional evaporation, large volumes of clean solvent could be obtained. The process is capable of removing $90 \%$ of Total Recoverable Petroleum Hydrocarbons (TRPH). But it has several limitations like the requirements of sub-zero ambient temperatures and large land surface. ${ }^{[11]}$

\subsection{Chemical treatment}

\subsubsection{Chemical precipitation}

The suspended solids and colloidal particles could be removed by coagulation and flocculation. Several coagulants like modified hot lime, FMA (a mixed metal polymer), Spillsorb, calcite and ferric ions were used as coagulant to treat produced water. The disadvantages of this process are its ineffectiveness for dissolved components and the increased concentration of metals in the sludge formed. ${ }^{[12,13]}$ 


\subsubsection{Chemical oxidation}

It uses a combination of strong oxidants (e.g: $\mathrm{O} 3$ and $\mathrm{H} 2 \mathrm{O} 2$ ), irradiation (e.g: UV) and a catalyst (e.g: photocatalyst), and oxidizes the organic components to their highest stable oxidation states. ${ }^{[14]}$

\subsubsection{Electrochemical process}

Almost $90 \%$ of BOD and COD could be removed from produced water in a short time (of the order of 6 minutes) by using an active metal and graphite as an anode and iron as a cathode. During the process, $\mathrm{Mn}^{2+}$ is formed, which oxidizes and coagulates the organic contaminants. ${ }^{[15]}$

\subsubsection{Photocatalytic treatment}

The $\mathrm{pH}$ of the solution is increased to a value of 11 by adding soda. The photochemical reaction was then carried out on the supernatant obtained from the flocculation unit. Titanium dioxide is usually used as photocatalyst. The COD removal efficiency and toxicity reduction were found to be higher in photoelectrocatalysis than that in photocatalysis. ${ }^{[16]}$

\subsubsection{Fenton process}

Nearly $95 \%$ of COD and dispersed oil content can be reduced by combining flocculation with the Fenton oxidation adsorption process. The flocculent used is poly-ferric sulfate. [17]

\subsubsection{Treatment with ozone}

Sonochemical oxidation could destroy BTEX compounds but the addition of hydrogen peroxide does not improve the efficiency. The process requires high initial and operating cost. ${ }^{[18]}$

\subsubsection{Room temperature ionic liquids}

The hydrophobic room temperature ionic liquids remove certain soluble organic components efficiently, but not much of the other contaminants. Hence, the screening of ionic liquids depends on the constituents of produced water.[19]

\subsubsection{Demulsifiers}

Some surfactants used as production chemicals are responsible for the stabilization of oilwater emulsions. They reduce the oil-water interfacial tension. Demulsifiers are surfaceactive agents that would disrupt the effects of surfactants. But a number of solids like silts, iron sulphide and paraffin, etc., present in the crude oil complicate the process. ${ }^{[20]}$ 


\subsection{Biological treatment}

The produced water could be treated with aerobic as well as anaerobic microorganisms. The microorganisms disintegrate the organic and ammonia compounds, but could not treat dissolved solids. ${ }^{[21]}$ The COD removal efficiency increased up to $90 \%$ while treating produced water with Bacillus sp. ${ }^{[22]}$

\section{Membrane treatment processes}

Conventional treatment methods are capable of removing suspended particles with particle size of $5.0 \mu \mathrm{m}$ or above.The disposal and reinjection regulations are becoming more stringent and the conventional methods are not able to treat produced water which can meet these regulations. ${ }^{[23]}$ The general specification for acceptable quality of oil-fields produced water for discharging into surface water (or re-injection) are less than $42 \mathrm{mg} / \mathrm{L}$ of oil/water, and less than $10 \mathrm{mg} / \mathrm{L}$ of Total Suspended Solids (TSS). ${ }^{[2]}$ Conventional treatment processes are not able to meet these water effluent standards. New technologies should be utilized to separate both fine particles and dissolved components. ${ }^{[23]}$

Membrane processes are a rather new separation process for treatment of produced water. Membrane separation processes, including microfiltration (MF), ultrafiltration (UF), nanofiltration (NF) and reverse osmosis (RO), are able to treat produced water and generate water with high standards to meet regulations. The driving force of the above mentioned membranes processes is pressure gradient.[23]

\subsection{Advantages of membrane technology}

Membrane technologies have some advantages that make them popular for produced water treatment processes:[25, 26]

- $\quad$ sludge reduction

- high quality of permeate

- $\quad$ smaller space needed

- $\quad$ ease of operation

- minimal impact on permeate quality with variation in feed water quality

- little or no chemicals required

- $\quad$ possibility for recycling of waste streams

- possibility for having an automated plant

- moderate capital costs

- ability to be combined easily with other separation processes

- low energy consumption

- continuous separation

But there may be some drawbacks for using membrane processes including concentration, polarization/membrane fouling, low selectivity or low flux and low membrane lifetime. 
According to the above mentioned advantages, that membrane separation processes can, in some circumstances, be viable for treatment of produced water. ${ }^{[25]}$

\subsection{Membrane properties}

There are different types of membrane processes, membrane materials, and feed water compositions, but the main goal of preparing the membranes is the same. An ideal membrane should:

- be mechanically resistant

- $\quad$ have a high permeate flowrate

- have a high selectivity for a specific component

Having high permeate flowrate means having large pore sizes. A high level of selectivity for a certain component is achievable with small pore sizes and the range of pore sizes should be narrow. The last two parameters present a dilemma, as one is in conflict with the other. The membrane mechanical resistance depends on the membrane thickness. Therefore the membrane should have a thin layer of material (the selective layer), narrow pore sizes, and high porosity. ${ }^{[27]}$

According the type of materials and mechanism of separations, membranes may be categorized as porous or dense. Separation of dense membranes is based on physicochemical interaction of permeate and the membrane material. Separation mechanism of porous membranes is based on the mechanical separation by size of permeates and pore sizes of membrane (sieving). ${ }^{[27]}$

\subsection{Types of membranes}

Membranes can be generally classified based on their structure or morphology. The detailed classification of membranes is reported in Table2. Symmetric and asymmetric membranes are two classes. Symmetric membranes have different types including isotropic microporous, nonporous dense membrane, and electrically charged membranes. Asymmetric membranes are divided into Loeb-Sourirajan anisotropic, thin-film composite anisotropic, and supported liquid membranes. ${ }^{[28]}$

Membranes can also be classified based on the type of materials like ceramic, inorganic, and composite membranes.

\subsubsection{Polymeric membranes}

Polymeric membranes have some advantages including high efficiency for the removal of particles, emulsified and dispersed oil; small size; low energy requirements, and being cheaper than ceramic membranes. They also have some disadvantages including the inability to separate volatile and low molecular weight compounds, fouling problems due to oil, sulfide or bacteria which may be required to be cleaned daily, an inability to be used at temperatures above $50^{\circ} \mathrm{C}$, and they also create the possibility of having radioactive byproduct in the effluent and need for some pre-treatment processes. [26] 


\begin{tabular}{|c|l|l|l|}
\hline Process & \multicolumn{1}{|c|}{$\begin{array}{c}\text { Mechanism of } \\
\text { separation }\end{array}$} & Material/Type & Typical Objective \\
\hline $\begin{array}{c}\text { Microfiltration } \\
\text { (MF) }\end{array}$ & $\begin{array}{l}\text { Separation by sieving } \\
\text { through macropores } \\
(>50 \text { nm) }\end{array}$ & $\begin{array}{l}\text { Polymeric and } \\
\text { inorganic / } \\
\text { Porous }\end{array}$ & $\begin{array}{l}\text { Removal of suspended solids, } \\
\text { large organic molecules, and large } \\
\text { colloidal particles including } \\
\text { microorganisms (used for } \\
\text { reducing colloidal suspensions } \\
\text { and turbidity) }\end{array}$ \\
\hline $\begin{array}{c}\text { Ultrafiltration } \\
\text { (UF) }\end{array}$ & $\begin{array}{l}\text { Separation by sieving } \\
\text { through mesopores } \\
(2-50 \text { nm) }\end{array}$ & $\begin{array}{l}\text { Polymeric and } \\
\text { inorganic / } \\
\text { Porous }\end{array}$ & $\begin{array}{l}\text { Removal of large dissolved solute } \\
\text { molecules and suspended } \\
\text { colloidal particles, including } \\
\text { bacteria and macromolecules such } \\
\text { as proteins }\end{array}$ \\
\hline $\begin{array}{c}\text { Nanofiltration } \\
\text { (NF) }\end{array}$ & $\begin{array}{l}\text { Separation through } \\
\text { combination of charge } \\
\text { rejection, solubility- } \\
\text { diffusion and sieving } \\
\text { through micropores } \\
\text { (<2 nm) }\end{array}$ & $\begin{array}{l}\text { Polymeric / } \\
\text { Dense }\end{array}$ & $\begin{array}{l}\text { Removal of multivalent ions and } \\
\text { specific charged or polar } \\
\text { molecules }\end{array}$ \\
\hline $\begin{array}{l}\text { Reverse osmosis } \\
\text { diffusion rates of } \\
\text { water and solutes }\end{array}$ & $\begin{array}{l}\text { Separation is based } \\
\text { on difference in }\end{array}$ & $\begin{array}{l}\text { Polymeric / } \\
\text { Dense }\end{array}$ & $\begin{array}{l}\text { Removal of low molecular weight } \\
\text { components such as inorganic } \\
\text { ions }\end{array}$ \\
\hline
\end{tabular}

Table 2. Membrane processes [26, 27]

Polymeric membranes are prepared from materials like polyacrylonitrile (PAN) and Polyvinylidenediflouride (PVDF). These membranes are relatively cheap. Polymeric membrane should be tested via integrity testing to be sure that they are not damaged. Their life cycle is approximately 7 years. Polymeric membranes can be used to treat feed streams containing high TDS contents. Their efficiency for dead-end and cross-flow operations are $85 \%$ and $100 \%$, respectively.[29]

\subsubsection{Inorganic membranes}

Inorganic membranes have better chemical and thermal stability than polymeric membranes. There are four different types of inorganic membranes, such as ceramic membranes, glass membranes, metallic membranes (including carbon), and zeolitic 
membranesm are utilized in MF and UF processes. Metallic membranes are prepared from metal powders like stainless steel, tungsten or molybdenum. Ceramic membranes are synthesized from a combination of metals like aluminium, titanium, silicium, or zirconium with non-metals like oxides, nitrides, or carbides. Aluminium oxide $\left(\gamma-\mathrm{Al}_{2} \mathrm{O}_{3}\right)$ and zirconium oxide $\left(\mathrm{ZrO}_{2}\right)$ are the most important materials for ceramic membranes. Glass membranes (silica or $\mathrm{SiO}_{2}$ ) can also be considered as ceramic membranes. Zeolite membranes are a new class of membranes which have a narrow pore size. ${ }^{[30]}$

\section{a. Ceramic membranes}

Ceramic membranes are prepared from nitrides, oxides, or carbides of metals like zirconium, titanium, or aluminum. Tubular modules have been the most widely used, and in which the feed flows inside the membrane channel. Tubular membranes consist of a porous support layer (typically $\alpha$-alumina), one or more decreasing pore diameter layers and an active layer responsible for separation ( $\alpha$-alumina, zirconia, etc.). ${ }^{29,26]}$

Ceramic membranes have some advantages including higher flux due to their higher porosity, more hydrophilic surface than organic membranes, better recovery performance of the membrane due to better resistance against mechanical, thermal, and chemical stress than organic membranes. ${ }^{[31,32]}$ The main advantage of ceramic membranes is its capability to meet the current water treatment effluent standards with no chemical pretreatment. ${ }^{[33]}$ Ceramic membranes have some disadvantages including sealing problems because of thermal expansion of ceramic membrane, and module housing. Ceramic membranes should be handled carefully as they are brittle.[31, ${ }^{32]}$ Another advantage of ceramic membranes is a greater removal of the particles at higher flux than polymeric membranes due to well-defined pore distribution of the ceramic membranes.

Membrane fouling is one of the problems associated with usage of membranes in produced water treatment processes, but the high chemical and thermal stability of the ceramic membranes will make the chemical and thermal cleaning methods possible; this is not the case for the polymeric membranes. ${ }^{[26]}$

Thermal and chemical stability of mullite ceramic membranes are very high compared to other ceramic membranes. They are very cheap as they can be produced by extruding kaolin clay.[32]

Organic matter, oil and grease, and metal oxides can be removed using ceramic membranes but dissolved ions and dissolved organics cannot be separated and some pre-treatment processes like pre-coagulation, straining or cartridge filtration should be utilized. Feed streams containing high amount of total dissolved solids (TDS) can be treated using ceramic membranes, but high ion-concentration may cause irreversible fouling. Based on several studies, it was concluded that ceramic membranes have better performance, lower energy requirement, longer life cycle (more than 10 years), but it requires higher capital cost, than polymeric membranes.[29]

Abadi et al. ${ }^{[31}$ used a tubular ceramic $\left(\alpha-\mathrm{Al}_{2} \mathrm{O}_{3}\right)$ microfiltration (MF) membrane with a pore size of $0.2 \mu \mathrm{m}$ and a stainless steel housing for the treatment of oily wastewater from API 
effluent of Tehran refinery. Effects of the transmembrane pressure (TMP), cross flow velocity (CFV) and temperature on permeate flux; total organic compound (TOC) and fouling resistance (FR) were investigated. The recommended working conditions were $1.25 \mathrm{bar}$ for the transmembrane pressure (TMP), 2.25 for the cross flow velocity (CFV) and $32.5^{\circ} \mathrm{C}$ for temperature. Backwashing was stated to be useful to prevent the declination in permeate flux. Oil and grease content was reduced to $4 \mathrm{mg} / \mathrm{L}$ therefore meeting the National Discharge Standard, and total organic compound removal efficiency was more than $95 \%$. These systems were recommended to replace the conventional wastewater treatment method.

In a different study, ceramic microfiltration was used for treating produced water from two onshore and two offshore pilot plants. Dispersed oil and suspended solids concentration were less than $5 \mathrm{mg} / \mathrm{L}$ and $1 \mathrm{mg} / \mathrm{L}$, respectively, in permeate stream. Produced water was pretreated to avoid membrane fouling. At suitable membrane pore size and cross velocity, flux was increased up to $1750 \mathrm{gal} / \mathrm{ft}^{2} \mathrm{D}$. ${ }^{[34]}$

\section{b. Zeolite membranes}

Zeolite membranes have attracted much research in separation of ions from aqueous solutions by reverse osmosis. The separation mechanism includes electrostatic repulsion (Donnan exlusion) at intercrystalline pore entrances and size exclusion of hydrated ions. These special kinds of separations have made the zeolite membrane a unique separation process for the removal of organics and electrolytes from water by RO processes. ${ }^{[35,36]}$

Zeolite membranes are mostly used in composite structure due to their high fragility. Composite zeolite membranes consist of a thin film of zeolite supported on a porous material like ceramics, metal glasses, and porous alumina. Among different support materials,alumina is the most widely used. Some studies for zeolite composite membranes will be presented in the following section. ${ }^{[37]}$

\section{c. Composite membranes}

Cui et al. ${ }^{[38]}$ reported in a study the application of zeolite/ceramic membranes in MF of oilwater emulsion. $\mathrm{NaA} / \alpha-\mathrm{Al}_{2} \mathrm{O}_{3}$ microfiltration membranes were produced by hydrothermal synthesis on porous ceramic tubes with inter-particle pore sizes of 0.2 to $1.2 \mu \mathrm{m}$. They were prepared and utilized for the separation of oil-water emulsion. Feed water containing 100$500 \mathrm{mg} / \mathrm{L}$ oil was treated to produce clean water $(<3 \mathrm{mg} / \mathrm{L}$ oil $)$. Fouling resistance of hydrophilic NaA membrane was better than tubular ceramic membrane. In general, zeolite membranes are cheaper than ceramic membranes. Silica and alumina reagents like TEOA and sodium aluminate may be used for preparing inexpensive zeolite membranes. The energy-intensive sintering process, which is widely used for preparing ceramic MF membranes, is not needed for preparing zeolite membranes. Zeolite membranes demonstrated good stability against oil fouling and caustic cleaning solutions. Oil rejection efficiency and flux were more than $99 \%$, and $85 \mathrm{Lm}^{-2} \mathrm{~h}^{-1}$ flux was obtained for water containing $100 \mathrm{mg} / \mathrm{L}$ oil.Backwashing with hot water and alkali solution did not affect the membrane performance. 
Li et al. ${ }^{[39]}$ used inorganic nano-sized alumina particles for the modification of tubular UF module equipped with Polyvinylidenedifluoride (PVDF) membranes. The PVDF- $\mathrm{Al}_{2} \mathrm{O}_{3}$ membrane was used to treat oily wastewater from an oil field.Chemical oxygen demand and total organic carbon retention efficiencies were $90 \%$ and $98 \%$, respectively. The type of process was cross-flow. It was seen that permeation performance was improved and flux was increased to twice that of unmodified one. The antifouling performance of modified membrane was favorable and flux recovery ratio increased to $100 \%$ by washing with $1 \mathrm{wt} \%$ (commercial) OP-10 surfactant solution. The permeation water quality met the requirement for oil field injection or drainage. Oil content and suspended solids content were both 1 $\mathrm{mg} / \mathrm{L}$ after membrane treatment, and was therefore demonstrated that $\mathrm{PVDF}-\mathrm{Al}_{2} \mathrm{O}_{3}$ composite membrane can be used in oily wastewater treatment.

Four commercial thin-film composite polyamide membranes including RO membrane, two ultra-low pressure RO membranes, and one NF membrane were used for treatment of produced water to reach the standards of potable and irrigation waters. Produced water from sandstone aquifers was treated using a two-stage membrane unit. TOC concentration was less than $200 \mu \mathrm{g} / \mathrm{L}$. The system can recover $60-80 \%$ iodide which causes the final concentration of iodide in retentate to be more than $100 \mathrm{mg} / \mathrm{L}$ and can be used for commercial iodide recovery purposes. ${ }^{[40]}$

Molecular sieve zeolite membranes were prepared on the inner surface of tubular $\alpha$-alumina substrate, and produced water was treated in a RO separation process. Good ion rejection and chemical and mechanical stabilities led to the conclusion that molecular sieve zeolite membrane can be used in produced water purification, while polymeric membranes have many problems with fouling and structure instability. The overall ion rejection was $98.4 \%$ for synthetically produced water. ${ }^{[36]}$

Li et al. ${ }^{[35]}$ looked into the separation of $\mathrm{NaCl}$ solutions in presence of counter-ions or at increased pressure and concentration from produced water employing a pure silicate zeolite membrane synthesized on a commercial tubular $\alpha$-alumina substrate (PALL, pore diameter $=0.2 \mu \mathrm{m}$ ). Ion and water transport are highly dependent on the operating pressure, feed ion concentration and solution chemical composition. Exponential increase of ion flux was due to increasing feed ion concentration. Reductions in ion rejection rate and water flux were seen in the presence of high valence cations. It was suggested that the MFI-type zeolite membrane can be used for the desalination of produced water.

d. Membrane bioreactor (MBR)

A membrane bioreactor (MBR) has two steps including the activated sludge process in which produced water is treated biologically and the membrane filtration process which biomass (activated sludge) is separated from treated water using the membrane. MF and UF are used for the separation process. Better effluent quality will be obtained using an MBR compared to conventional activated sludge process. ${ }^{[41]}$

Use of membrane bioreactors has some advantages over conventional methods for treating produced water which includes lower energy costs, compactness, no need for chemical 
additives, low sludge production, high loading rate capacity and high quality of the treated water. ${ }^{[42]}$ There are few studies available for treatment of produced water using an MBR.

e. Membrane distillation

Membrane distillation (MD) is a separation process based on a thermally driven membrane. Vapour pressure gradient is the driving force for mass transfer through the membrane. MD is the only membrane separation process where the performance does not change with changing of feed TDS content. Operating cost of MD is lower than conventional distillation processes. The following materials are typically used for MD: Polyvinylidenedifluoride (PVDF), Polypropylene (PP), and Polytetrafluoroethylene (PTEE). Flat-sheet and hollowfiber are two typical modules for MD. Direct contact MD (DCMD), vacuum MD (VMD), seeping gas MD (SGMD), and air gap MD (AGMD) are four different methods of MD operation. ${ }^{[29]}$

Direct contact membrane distillation (DCMD) separation process utilizes a hydrophobic microporous membrane which in one side has a hot brine feed and on the other side a cold distillate stream. Water vapor passes through the membrane pores from the hot brine section. For treating hot brines, if reverse osmosis (RO) process was to be used, the feed should first be cooled which requires some energy, but DCMD process can treat hot feed streams without cooling which is an advantage of DCMD over RO process. Furthermore, the application of DCMD process above $100^{\circ} \mathrm{C}$ eliminates porous substrates which are required for low temperatures. ${ }^{[43]}$

Produced water feeds with TDS content of more than $35000 \mathrm{mg} / \mathrm{L}$ can be processed using $\mathrm{MD}$ and all non-volatile solutes (like $\mathrm{Na}, \mathrm{B}$ and heavy metals) are rejected with a theoretical efficiency of $100 \%$, but the diffusivity of compounds having higher volatility than water, diffuse faster through the membrane. As a pre-treatment, pre-filtration of feed is required to remove all compounds which may wet the hydrophobic surface of the membrane. MD systems have larger footprint than nanofiltration or reverse osmosis systems. ${ }^{29]}$

\subsection{Fouling}

In the treatment of produced water using membranes, the permeate flux may be decline. This declination may be due to concentration polarization or fouling ${ }^{[26]}$. Two general types of membrane fouling exist for oily waste water treatment including reversible fouling and irreversible fouling. Reversible fouling is a result of deposited colloidal particles or solutes on the membrane surface and in the membrane pores. Pure water backwashing may be utilized to reverse the flux declination in reversible fouling. Irreversible fouling is a result of strong chemical or physical sorption of particles and solutes on the membrane surface and in the pores. The only method for recovering the flux declination by irreversible fouling may be washing with acid or alkali solutions. However, aggressive cleaning methods may not be able to recover the initial permeability of irreversibly fouled membranes ${ }^{[39]}$.

Membrane fouling may be due to biofouling, scaling, organic fouling, and colloidal fouling: $[26,44]$ 
- microbial contamination of water may produce a biofilm on the surface of the membrane which will decrease water permeation through the membrane (biofouling).

- $\quad$ salts may precipitate on the membrane surface which will cause scaling.

- coating the surface or plugging the pores in the porous support layer by hydrocarbons is called organic fouling.

- accumulation of clay and silica on the surface of the membrane will cause colloidal fouling.

The mechanism of fouling has not been clearly identified yet because measurements taken from laboratory-scale processes cannot truly describe or explain the fouling phenomenon in pilot-scale or full-scale membrane processes. ${ }^{[45]}$ Many feed streams which are processed using membranes have particles with sizes from nanometers to micrometers which cause membrane fouling and because of this problem membrane fouling may not be stopped. [32]

Different strategies can be utilized to mitigate the effect of fouling: [46]

- $\quad$ oil, solids, and gels can be reduced using some pre-treatment processes

- keeping high cross-flow velocity on the feed side

- a cleaning cycle may be utilized

- backwashing or reverse flow washing may be used

- operating at higher temperatures

Coagulation, granular activated carbon and low pressure membrane processes (e.g., MF and UF membranes) are some of the pre-treatment methods which can be utilized before high pressure membranes to prevent fouling. ${ }^{[45]}$ Addition of disinfectants and anti-scaling agents may control fouling. ${ }^{[26] T h e ~ m o s t ~ p o s s i b l e ~ f o u l a n t ~ f o r ~} \mathrm{NF}$ and $\mathrm{RO}$ membranes after a UF treatment process could be calcium bound to inorganic materials and silica bound to organic materials. ${ }^{[45]}$

Membrane fouling is a function of feed properties (ionic strength, $\mathrm{pH}$, particle concentration, and particle size), membrane properties (pore size, charge, and hydrophibicity) and hydrodynamics (transmembrane pressure and cross-flow velocity). One of the most important parameters in controlling the flux is the cross-flow velocity. As pressure increases, flux increases linearly. A cross-flow velocity of $3 \mathrm{~m} / \mathrm{s}$ was reported as normal velocity, operation above it may reduce the rate of fouling, however utilization of higher pressures needs more energy and very high pressures (consequently high velocities) may result in severe fouling or membrane compaction. ${ }^{26]}$

Hydrophilic membranes experience reduced fouling problems because their adsorptivity of hydrocarbons are less than hydrophobic membranes. Many methods including surface segregation, surface coating, and surface graft polymerization may be used for increasing the hydrophilicity of membranes. Some polymers including polyvinylidene fluoride (PVDF), polymethyl methacrylate (PMMA), polymethyacrylate (PMA), polyvinylacetate (PVAc), and cellulose acetate (CA) may be used for blending as hydrophilic polymers to increase the hydrophilicity of membranes. Blending of inorganic materials was shown to increase the membrane permeability and the membrane surface properties was better controlled than blending of organic materials ${ }^{[44,39]}$. 
Maguire-Boyle et al. ${ }^{[44]}$ used alumina nanoparticles (alumoxanes) stabilized with hydrophilic cysteic acid to prepare the surface functionalized alumina fabric composite membranes. It was observed that surface chemistry of the membrane may be changed by coating. They consequently have better permeability of water compared to hydrocarbons.

Hydrophilicity of a membrane was increased in a study ${ }^{[46]}$ but it was seen that adhesion of some components of oil and chemicals in produced water changed the wettability of the surface and degradation in membrane performance was observed over time.

Nanofiltration (NF) membranes can be used at lower pressures than reverse osmosis (RO) membranes but fouling is a problem for NF membranes which will increase the transmembrane pressure and reduce the flux. A trial-and-error method can be used to control fouling and clean the membranes. Membrane fouling may be controlled by changing the surface chemistry of the membrane. Mondal and Wickramasinghe used polyamide based thin film composite (TFC) membrane surfaces and modified them by photo-induced grafting of $\mathrm{N}$-isopropyl acrylamide. It was seen that the hydrophobicity of the membrane surface was increased substantially which would control fouling ${ }^{[47]}$.

Pedenaud et al. ${ }^{[48]}$ reported that if produced water contained sufficient level of barium and sulfate, it may cause irreversible fouling on ceramic membranes and have very low long term filtration, and in order to prevent precipitation, a suitable anti-scalant should be used.

Another surface modification process study was conducted by Wandera et al. ${ }^{[9]}$ to reduce membrane fouling. A low molecular weight cut-off cellulose ultrafiltration membrane was modified utilizing surface-initiated atom transfer radical polymerization. Utilizing this method limited the fouling and, when it occurred, foulants were removed without using chemicals. The rate of decrease in water flux was slowed and finally flux recovery got better than in the unmodified membrane. It was stated that this modification process can be used for other membrane materials to reduce the fouling problem.

\subsection{Cleaning methods}

There are different methods to clean membranes in order to reduce fouling problems which includes cross-flushing, back-flushing, use of chemicals, and use of ultrasound:[26]

- $\quad$ air bubbles in forward washing (AirFlush) may be utilized for membrane cleaning (cross-flushing)

- reversion of flow direction through permeate channel to feed channel may be utilized in back-washing method but in cases where adsorbents were strongly adsorbed to the membrane surface this method may not be very useful

- $\quad$ some chemicals may be utilized including acids (calcium salts and metal oxides may be dissolved), alkalis (silica, organic/biological foulants, and inorganic colloids may be removed), surfactants (displace foulants, dissolve hydrophobic foulants, and emulsify oils), oxidants (bacteria and organic compounds may be oxidized), sequestrates (metal cations may be removed from a solution), and enzymes (foulants may be degraded) 
- utilization of ultrasound method may be useful in increasing membrane flux by breaking cake layer or by decreasing solute concentration at membrane surface

Among the cleaning methods, backwashing has been used widely but is not recommended as the membrane usually experiences a reduction in permeate flux after each backwash. Another problem with backwashing is that the operation must be stopped to backwash the membrane. ${ }^{[26]}$ Chemicals used for membrane cleaning were lye solutions $(1 \%(\mathrm{w} / \mathrm{w}) \mathrm{NaOH}$ solution, Ultrasil P3-14, Ultrasil P3-10 for 30 to $60 \mathrm{~min}$ ). Washing intervals depends on the oil and grease concentration in the feed, permeate flow rate, success of washing, and the period of membrane degradation. ${ }^{[46]}$

\subsection{Modelling}

Membrane fouling crucially depends on the permeate flux. Usually there is a rapid decrease in permeate flux and then flux decreases gradually with time. As a result, modeling of the fouling process is important. Three different types of models exist for the description of the permeate flux decline. Empirical models are accurate but cannot explain the fouling mechanisms. Fouling mechanisms can be described by theoretical models but these models cannot give accurate results for flux reduction with time. Semi-empirical models which have their parameters estimated from experimental data can accurately predict the flux decline and interpret the fouling mechanism. ${ }^{[32]}$

Blocking models may be used for prediction of filtration flux from analyses of blocking chart and resistance coefficients. Pore blocking is caused by bulk phase particles that are small enough to enter and deposit inside the pore. There are three types of blocking models. The standard pore blocking happens when the particle/droplet size is smaller than the mean pore size of the membrane. It is called adsorptive fouling or pore narrowing. Complete pore blocking occurs when particle/droplet size is approximately equal to the mean pore size of the membrane. Intermediate pore blocking occurs when more particles/droplets settle over already deposited particles/droplets. Standard pore blocking, Complete pore blocking and Intermediate pore blocking models can be used to obtain the permeate flux. Blocking chart is a graph drawn between the permeate flux (q) and the particle accumulation (cv), from which the blocking index(i) can be obtained. The resistance coefficient $(\mathrm{K})$ can be found using the following equation.

$$
\frac{d^{2} t}{d v^{2}}=K\left(\frac{d t}{d v}\right)^{i}
$$

Where $\mathrm{v}$ is the filtrate volume, $\mathrm{t}$ is time, and $\mathrm{i}$ is the blocking index.

Abbasi et al. ${ }^{[32]}$ studied the fouling mechanism in cross-flow microfiltration (MF) of a synthesized oily wastewater. They stated that the cake formation model had the best results when compared to experimental data. The intermediate pore blocking model had the best results for the prediction of the flux after the cake formation model, and the worst result pertained to the pore blocking model. 


\section{Combined systems}

Membrane treatment processes can be very efficient for the treatment of oily waste water but the utilization of membranes as the only unit for treatment of produced water may cause severe fouling of the membranes due to the presence of high level of oil, suspended solids, and bacteria. Therefore, some pre-treatment processes are required before membrane processes.[50]Removal of salts and many of the associated organics and inorganics can be achieved using the RO process. However, a pre-treatment step such as acidification is needed for the removal of low molecular weight organics and inorganics like boron, and the utilization of RO process without a pre-treatment step cannot be effective and some post treatment processes may also be needed after the $\mathrm{RO}$ process to meet the required standard. [51]

Treatment processes depend on the characteristics of produced water and these differ from well to well. Some experimental studies for determination of characteristics of produced water are required for designing a treatment process, relying solely on the literature is not recommended. ${ }^{[52]}$

Lee and Frankiewicz ${ }^{[46]}$ recommended using some pre-treatment processes to reduce the oil and solids contents to less than $50 \mathrm{ppm}$ and $15 \mathrm{ppm}$ respectively, before utilizing a hydrophilic UF membrane with a pore size of $0.01 \mu \mathrm{m}$ to reduce the fouling problem. It was stated that if the oil concentration can be reduced to less than $50 \mathrm{ppm}$, the membrane permeability can be maintained in an acceptable value for 4 days or longer with washing at several intervals. A daily washing was necessary for treating a feed stream containing 200 ppm as oil concentration but the washing intervals extended to 6 to 8 days for an oil concentration of $25-50 \mathrm{ppm}$ by utilizing some pre-treatment processes. De-sanding and de-oiling hydrocyclones and pre-filtering are examples of pre-treatment processes used. The removal efficiency of hydrocyclone for solids and oils were $73 \%$ and $54 \%$ respectively in the pre-treatment processes. Total oil and grease content was less than $2 \mathrm{mg} / \mathrm{L}$ in the permeate stream and the efficiency of water recovery was $98 \%$.

Some experiments were conducted to treat produced water for irrigation quality standards and to model the oil and salt separation processes. The proposed process included microfiltration, utilizing sorption pellets made of a modified clay material (organoclay PS12385) and reverse osmosis (RO) units for separation of salts. The average loading capacity of clay pellets was better than the activated carbon (more than $60 \%$ ) and it was seen that packed bed can separate more than $90 \%$ of the oil. The RO membrane can separate more than $95 \%$ of TDS. This process may be used to recover up to $90 \%$ of water from produced water. Utilizing two membranes in series with lower surface area for the second membrane than the first membrane may give similar results to membranes in parallel at a lower capital cost. ${ }^{[53]}$ Note that, for produced water, Benko puts the cost of material for ceramic membranes at $\$ 180 / \mathrm{ft}^{2}$ and that of polymeric membranes at $\$ 40 / \mathrm{ft}^{2}$. If productivity is the criteria, then the cost becomes $\$ 60$ and $\$ 20$ for ceramic and polymeric membranes, respectively. [60] 
In a process, boron and solubilized hydrocarbons were separated from aqueous liquids such as produced water. In this study divalent ions were removed by adding a water softener to the water and raising the $\mathrm{pH}$ to about 9.5. The liquid was then passed through a composite polyamide reverse osmosis (RO) membrane. The efficiency of method was able to reduce boron concentration to less than $2 \mathrm{mg} / \mathrm{L}$. ${ }^{[54]}$

A pilot plant including aeration tank, air floatation, sand filter and UF membrane was used for treating produced water for discharge or injection into an oil-well purposes. It was shown that oil and suspended solid contents were reduced to less than $0.5 \mathrm{mg} / \mathrm{L}$ and 1.0 $\mathrm{mg} / \mathrm{L}$. The concentration of Fe and some bacteria also met the required standard for injection and discharging purposes. ${ }^{[50]}$

Çakmakci et al. ${ }^{[52]}$ utilized dissolved air floatation (DAF), acid cracking (AC), coagulation (CA) with lime and precipitation, cartridge filters (CDF), microfiltration (MF) and ultrafiltration (UF) as pre-treatment processes and nanofiltration (NF) and reverse osmosis (RO) were used to reduce the salt content. To obtain the best effluent quality and high permeate flux different combinations of treatment methods were tested. A combination was suggested to reduce COD to less than $250 \mathrm{mg} / \mathrm{L}$.

In a pilot study, produced water was treated for industrial, irrigation and potable water use. The proposed unit included warm softening, coconut shell filtration, cooling (fin-fan), trickling filter, ions exchange and reverse osmosis. Silica level was reduced to $3 \mathrm{mg} / \mathrm{L}$ by adding $400 \mathrm{mg} / \mathrm{L} \mathrm{MgCl}_{2}$. Hardness, TDS, boron and ammonia were removed up to $95 \%$, $95 \%, 90 \%$ and $80 \%$, respectively. [55]

A configuration of the process was suggested including wash tanks, dissolved gas floatation, walnut shell filtration, warm lime softening, membrane bioreactor and reverse osmosis to reach potable and irrigation water standards. ${ }^{[56]}$

Doran et al. ${ }^{[57]}$ used a combination of warm precipitate softening at $\mathrm{pH} 9.7$, cooling, fixedfilm biological organics oxidation, pressure filtration, ion-exchange softening and reverse osmosis to treat produce potable water. ${ }^{[57]}$

A pilot-scale hybrid reverse osmosis process was used to treat produced water for irrigation or discharge to surface waters. It was suggested that decreasing the conductivity may reduce the salt concentration. After treatment, the conductivity was reduced by $98 \%$ and TDS by $96 \%$ which was found to be an acceptable level for irrigation or discharge to surface waters. [51]

\section{Commercial treatment processes}

\subsection{RO based processes}

\subsubsection{CDM Technology}

CDM Smith produces a technology that is a combination of three major processes such as ion exchange process, reverse osmosis and evaporation. It is mostly used to treat high TDS 
coal bed methane (CBM) produced water. UV disinfection is also included to reduce the bacterial activity. The total cost of treatment per barrel of produced water was found to be $\$$ 0.30. The inclusion of pre-treatment processes reduced the membrane fouling to a great extent, and water recovery ranged from $50 \%$ to $90 \%$. ${ }^{[62,29]}$

\subsubsection{Veolia: OPUS ${ }^{T M}$ - Optimized pre-treatment and separation technology}

It is designed to treat sparingly soluble solutes (e.g., $\mathrm{SiO}_{2}, \mathrm{CaSO}_{4}$, and $\mathrm{Mg}(\mathrm{OH})_{2}$ ), organics, and boron. The raw produced water is acidified and degasified. It is followed by Multiflo ${ }^{\mathrm{TM}}$ chemical softening, which is a series of coagulation, flocculation and sedimentation. Decant from sedimentation is fed into packed-bed media filtration column. The microorganisms present would be removed by IX resin. Water is then pressurized and treated by BWRO (Brackish Water Reverse Osmosis) membrane at high $\mathrm{pH}$. The entire process system could fit on a cargo trailer. Produced water recovery is estimated to be greater than $90 \%$. ${ }^{[62,29]}$

\subsubsection{Eco-sphere: Ozonix ${ }^{T M}$}

Ozonix $^{\mathrm{TM}}$ is primarily used for the treatment of frac flow-back water, but it could also be used for produced water treatment. The feed water is mixed with supersaturated ozonized water in a reaction vessel. The hydroxyl radicals, formed from ozone, readily oxidize metals, and decompose soluble and insoluble organic compounds and microorganisms. The reaction vessel had two electrodes to induce precipitation of hard salts. Water is then treated with activated carbon cartridge filter and a RO membrane. Water recovery approaches $75 \%$. ${ }^{[29]}$

\subsubsection{GeoPure water technologies}

The GeoPure desalination process is a combination of pre-treatment, ultrafiltration and reverse osmosis. This technology was developed for the treatment of oil and natural gas produced waters. Water recovery was reported to be $50 \% .{ }^{[29]}$

\subsection{Ion-Exchange (IX) based processes}

\subsubsection{EMIT: Higgins Loop}

EMIT Higgins Loop technology is widely used for CBM produced water treatment. The Higgins Loop is a continuous counter current ion exchange contactor for liquid phase separations of ionic components. The IX resin adsorbs sodium ions in exchange of hydrogen ions. Hence the $\mathrm{pH}$ of water is reduced which eventually reduces bicarbonate levels. The resin saturated with sodium ions are regenerated by $4.11 \mathrm{M} \mathrm{HCl}$. Product water recovery typically exceeds $99 \% .{ }^{[29]}$

\subsubsection{Drake: Continuous selective IX process}

The Drake system is a three-phase, continuous fluidized bed system to remove monovalent cations. A strong acid cation exchange resin is used. Energy requirements are slightly less 
than that required for the EMIT Higgins Loop system. The maximum product water recovery is reported to be $97 \% .{ }^{[29]}$

\subsubsection{Eco-Tech: Recoflo ${ }^{\circledR}$ compressed-bed IX process}

The Eco-Tech compressed bed systems are an extension of conventional packed bed IX processes. One system has two separate compressed-bed columns for anion and cation removal. Another system has three separate compressed-bed columns that contain a primary cation bed and anion bed followed by a polishing cation bed. Recoflo® systems are primarily used for recovering metals from effluent electrolytes. These are more mobile than conventional and Higgins Loop processes. A system has been installed in Powder River Basin to treat 1.5 Mgd of CBM produced water. ${ }^{62,29]}$

\subsubsection{Catalyx Fluid Solutions/RGBL IX process}

It was designed to minimize resin wastage during regeneration. The sodium and bicarbonate ions are removed by ion exchange chemical reaction.

$$
\mathrm{Na}^{+}+\mathrm{HCO}_{3}^{-}+\mathrm{R} \ldots \mathrm{H}^{+} \rightarrow \mathrm{R} \ldots \mathrm{Na}^{+}+\mathrm{H}_{2} \mathrm{O}+\mathrm{CO}_{2}
$$

Waste minimization is done by the use of three tanks that are responsible for shuffling regenerating agent and rinse waters of various qualities during IX resin regeneration cycles. ${ }^{[29]}$

\section{Conclusion}

Produced water may be treated using different methods of operation. The criteria used to compare the technologies are in general, robustness, reliability, mobility, flexibility, modularity, cost, chemical and energy demand, and brine or residual disposal requirements.Many process and water quality specific factors should be taken into account when selecting a produced water treatment process. Temperature of the feed water may help determine which type of desalination treatment process should be employed since many technologies work more efficiently at high temperatures, while others use feed stream at low temperature. On the other hand if ion removal is necessary, it is important to consider the type of ions that need to be removed. Membrane processes most often remove divalent ions to a greater extent than monovalent ions, which may make the sodium adsorption ratio higher and render the water less suitable for beneficial use as irrigation water or surface discharge. ${ }^{[62]}$ Membrane processes can treat produced water to meet many water quality requirements. Fouling is one of the major drawbacks of membranes which depends on permeate flux and its stability on time, but can be minimized by using hydrophobic membranes.

Modeling of permeate flux decline in crossflow filtration of oily wastewater is important from both the economical and technological points of view. Empirical models are the most accurate, but need experimentation and are not capable of making accurate predictions. Theoretical models are useful for the prediction of permeate flux under different operating 
conditions without the need for time-consuming experiments but there is no theoretical model that can accurately describe the crossflow filtration process. Therefore, it is required to work on the improvement of the theoretical models to make more accurate predictions and to better understand the fouling mechanisms.

Some pre-treatment methods should be utilized before membrane processes to increase the membrane life cycle. Different membrane units can be used as a polishing step. Each method has some advantages as well as some disadvantages and a combination of methods may be more useful for treatment of produced water to meet the different water quality requirements. Utilization of a certain type of process or combination of processes is highly dependent on the characteristics of the produced water.

Characteristics of produced water differ from well to well and the determination of the produced water characteristics is required. The design of a treatment process wholly based on the literature is not possible.Finally, the unpredictable and rapid onset of upsets in the produced water treatment process often results in unplanned maintenance and production losses.

Ceramic membranes may be a viable treatment technology for many produced water applications. Ceramic membranes will most likely be needed as a pre-treatment technology if desalination is required. While the capital cost of ceramic membrane is presently higher than polymeric, a ceramic membrane offers advantages over a polymeric membrane such as increased chemical, mechanical and thermal stability, and therefore higher lifespan and higher productivity.

International standards demand more efficient separation systems than those now in common use.More research and development is required in membrane development as, although many new products show promises, membrane filtration is still considered at the development stages. Effluent streams that once were treated as "waste" will then be considered a valuable "resource" but, unknown toxic effects and public acceptance are also important barriers for potable reuse of all wastewaters.

\section{Author details}

Rangarajan T. Duraisamy, Ali Heydari Beni and Amr Henni

Industrial/Process Systems Engineering , Faculty of Engineering and Applied Sciences, University of Regina, Regina, Saskatchewan, Canada

\section{Acknowledgement}

The authors would like to acknowledge the financial help in a form of two grants (equipments and operations) from Western Economic Diversification Canada, Entreprise Saskatchewan (Saskatchewan Government) and the Petroleum Technology Research Centre (PTRC-Regina). 


\section{References}

[1] Ahmadun F.-R., Pendashteha A., Abdullaha L. C., Biaka D. R. A., Madaenic S. S., Abidina Z. Z. (2009) Review of technologies for oil and gas produced water treatmen. Journal of Hazardous Materials. 170 (2-3): 530-551.

[2] Doyle D. and Brown A. (2000) Produced Water treatment and hydrocarbon removal with organoclay. in SPE Annual Technical Conference and Exhibition, Dallas, Texas.

[3] Carvalho M., Clarisse M., Lucas E. and Barbosa C. (2002) Evaluation of the polymeric materials (DVB copolymers) for produced water treatment. in SPE International Petroleum Exhibition and Conference, Abu Dhabi, 2002.

[4] Janks J. and Cadena F. (1992) Investigations into the use of modified zeolites for removing benzenes, toluene and xylene from saline produced water. in Produced Water: Technological/Environmental Issues and Solutions, New York, Plenum Publishing Corp.: 473-488.

[5] Plebon M., Saad M. and Fraser S. (2005) Further Advances in Produced Water De-oiling Utilizing a Technology that Removes and Recovers Dispersed Oil in Produced Water 2 micron and Larger. Available: http://www.ipec.utulsa.edu/.

[6] Adewumi M., Erb J. and Watson R.W. (1992) Design considerations for a cost effective treatment of stripper oi lwell produced water. In Produced Water: Technological/Environmental Issues and Solutions, New York, Plenum Publishing Corp.: 511-523.

[7] Knudsen B., Hjelsvold M., Frost T., Grini P., Willumsen C. and Torvik H. (2004) Meeting the zero discharge challenge for produced water.Proceeding of the Seventh SPE International Conference on Health, Safety, and Environment in Oil and Gas Exploration and Production, Calgary, 2004.

[8] Broek W. V. d. and Zande M. V. d. (1998) Comparison of plate separator, centrifuge and hydrocyclone. SPE International Oil and Gas Conference and Exhibition, Beijing, 1998.

[9] Becker R. B. (2000) Produced and process water recycling using two highly efficient systems to make distilled water.SPE Annual Technical Conference and Exhibition, Dallas , 2000.

[10] Thoma G., Bowen M. and Hollensworth D. (1999) Dissolved air precipitation solvent sublation for oilfield producedwater treatment.Separation and Purification Technology. 16: 101-107.

[11] Boysen J. and Boysen D. (2008) The Freeze-Thaw/Evaporation (FTE) process for produced water treatment, disposal and beneficial uses. Available:

http://ipec.utulsa.edu/Conf2008/Manuscripts\%20\&\%20presentations\%20received/Boyse n_37_FreezeThaw.pdf.

[12] Garbutt C. (1997) Innovative treating processes allow steam flooding with poor quality oilfield water.SPE Annual Technical Conference and Exhibition, San Antonio, 1997.

[13] Zhou F., Zhao M., Ni W., Dang Y., Pu C. and Lu F. (2000) Inorganic polymeric flocculent FMA for purifying oilfield produced water: preparation and uses.Oilfield Chemistry. 17, 256-259.

[14] Renoua S., Givaudana J., Poulaina S., Dirassouyanb F. and Moulin P. (2008) Landfill leachate treatment: Review and opportunity.Journal of Hazardous Materials. 150(3): 468-493. 
[15] Ma H. and Wang B. (2006) Electrochemical pilot-scale plant for oil field produced wastewater by M/C/Fe electrodes for injection.Journal of Hazardous Materials. B132: 237-243.

[16] Li G., An T., Nie X., Sheng G., Zeng X., Fu J., Lin Z. and Zeng E. (2007) Mutagenicity assessment of produced water during photoelectrocatalytic degradation.Environmental Toxicology and Chemistry. 26: 416-423.

[17] Yang Z. and Zhang N. (2005) Treatment of produced wastewater by flocculation settlement-Fenton oxidation-adsorption method.Xi'an Shiyou University(Natural Science). 20: 50-53.

[18] Morrow L., Martir W., Aghazeynali H. and Wright D. (1999) Process of treating produced water with ozone". USA Patent 5,868,945.

[19] McFarlane J., Ridenour W., Luo H., Hunt R., Paoli D. D. and Ren R. (2005) Room temperature ionic liquids for separating organics from produced water.Separation Science and Technology. 40: 1245-1265.

[20] Deng S., Yu G., Jiang Z., Zhang R. and Ting Y. (2005) Destabilization of oil droplets in produced water from ASP flooding.Colloids and Surfaces. 252: 113-119.

[21] Palmer L., Beyer A. and Stock J. (1981) Biological oxidation of dissolved compounds in oilfield produced water by a field pilot biodisk.J. Petrol. Technol. 8308-PA: 1136-1140.

[22] Li Q., Kang C. and Zhang C. (2005) Waste water produced from an oilfield and continuous treatment with an oil-degrading bacterium.Process Biochem. 40: 873-877.

[23] Li L. and Lee R. (2009) Purification of Produced Water by Ceramic Membranes: Material Screening, Process Membranes. Separation Science and Technology. 44: 3455-3484.

[24] Bader M. (2007) Seawater versus producedwater in oil-fields water injection operations.Desalination. 208: 159-168.

[25] Mondal S. and Wickramasinghe S. R. (2008) Produced water treatment by nanofiltration and reverse osmosis membranes.Journal of Membrane Science. 322: 162-170.

[26] Ashaghi K. S., Ebrahimi M. and Czermak P. (2007) Ceramic Ultra- and Nanofiltration Membranes for Oilfield Produced Water Treatment: A Mini Review.The Open Environmental Journal. 1: 1-8.

[27] Judd S. and Jefferson B. (2003) Membranes for Industrial Wastewater Recovery and Reuse. Oxford: Elsevier Advanced Technology.

[28] Baker R. W. (2004) Membrane Technology and Applications, Second Edition. England: John Wiley \& Sons, Ltd.

[29] Technical Assessmentof Produced Water Treatment Technologies. Colorado School of Mines. Available:

http://aqwatec.mines.edu/produced_water/treat/docs/Tech_Assessment_PW_Treatment _Tech.pdf. Accessed November 2009.

[30] Mulder M. (1996) Basic Principles of Membrane Technology, second edition. Dordrecht, The Netherlands: Kluwer Academic Publishers.

[31] Abadi S. R. H., Sebzari M. R., Hemati M., Rekabdar F. and Mohammadi T. (2011) Ceramic membrane performance in microfiltration of oily wastewater.Desalination. 265: 222-228.

[32] Abbasi M., Sebzari M. R., Salahi A. and Mirza B. (2012) Modeling of Membrane Fouling and Flux Decline in Microfiltration of Oily Wastewater Using Ceramic Membranes.Chemical Engineering Communications. 199: 78-93. 
[33] Ebrahimi M., Willershausen D., Ashaghi K. S., Engel L., Placido L., Mund P., Boldaun P. and Czermak P. (2010) Investigations on the use of different ceramic membranes for efficient oil-field produced water treatment.Desalination. 250: 991-996.

[34] Chen A., Flynn J., Cook R. and Casaday A. (1991) Removal of oil, grease, and suspended solids from producedwater with ceramic crossflow microfiltration.SPE Prod. Eng. 6: 131-136.

[35] Li L., Liu N., McPherson B. and Lee R. (2008) Influence of counter ions on the reverse osmosis through MFI zeolite membranes: implications for producedwater desalination.Desalination. 228: 217-225.

[36] Liu N., Lu J., Li L. and Lee R. (2007) Factors determining the reverse osmosis performance of zeolite membranes on producedwater purification. in Factors determining the reverse osmosis performance of zeolite membranes on producedwater purification, Houston, Texas, USA, 2007.

[37] Valtchev V. (2005)Verified Syntheses of Zeolitic Materials, 2nd Revised Edition, Preparation of zeolite membranes," Laboratoire de Matériaux, Minéreaux. Available: http://www.izaonline.org/synthesis/VS_2ndEd/Membranes.htm. Accessed 2005 Nov 16.

[38] Cui J., Zhang X., Liu H., Liu S. and Yeung K. L. (2008) Preparation and application of zeolite/ceramic microfiltration membranes for treatment of oil contaminated water.Journal of Membrane Science. 325: 420-426.

[39] Li Y. S., Yan L., Xiang C. B. and Hong L. J. (2006) Treatment of oily wastewater by organicinorganic composite tubular ultrafiltration (UF) membranes.Desalination. 196: 76-83.

[40] Xu P., Drewes J. E. and Heil D. (2008) Beneficial use of co-producedwater through membrane treatment: technical-economic assessment.Desalination. 225: 39-155.

[41] Li N. N., Fane A. G., Ho W. S. W. and Matsuura T. (2008) Advanced Membrane Technology and Applications, New Jersey: A John Wiley \& Sons, Inc., Publication.

[42] Kose B., Ozgun H., Ersahin M. E., Dizge N., Koseoglu-Imer D., Atay B., Kaya R., Altınbas M., Sayılı S., Hoshan P., Atay D., Eren E., Kinaci C. and Koyuncu I. (2012) Performance evaluation of a submerged membrane bioreactor for the treatment of brackish oil and natural gas field produced water.Desalination. 285: 295-300.

[43] Singh D. and Sirkar K. K. (2012) Desalination of brine and producedwater by direct contact membrane distillation at high temperatures and pressures.Journal of Membrane Science. 389: 380-388.

[44] Maguire-Boyle S. J. and Barron A. R. (2011) A new functionalization strategy for oil/water separation membranes.Journal of Membrane Science. 382: 107-115.

[45] Chon K., Kim S. J., Moon J. and Cho J. (2012) Combined coagulation-disk filtration process as a pretreatment of ultrafiltration and reverse osmosis membrane for wastewater reclamation: An autopsy study of a pilot plant. Water Research. 46: 18031816.

[46] Lee J. and Frankiewicz T. (2005) Treatment of Produced Water With an Ultrafiltration (UF) Membrane - A Field Trial. in SPE Annual Technical Conference and Exhibition, Dallas, Texas, 2005.

[47] Mondal S. and Wickramasinghe S. (2012) Photo-induced graft polymerization of N isopropyl acrylamide on thin film composite membrane: Produced water treatment and 
antifouling properties. Separation and Purification Technology.doi: 10.1016/j.seppur.2012.02.024.

[48] Pedenaud P., Heng S., Evans W. and Bigeonneau D. (2011) Ceramic Membrane and Core Pilot Results for Produced Water Management. in Offshore Technology Conference, Rio de Janeiro, Brazil, 2011.

[49] Wandera D., Wickramasinghe S. R. and Husson S. M. (2011) Modification and characterization of ultrafiltration membranes for treatment of produced water.Journal of Membrane Science. 373: 178-188.

[50] Qiao X., Zhang Z., Yu J. and Ye X. (2008) Performance characteristics of a hybrid membrane pilot-scale plant for oilfield produced wastewater.Desalination. 225: 113-122.

[51] Murray-Gulde C., Heatley J. E., Karanfil T., Rodgers Jr. J. H. and Myers J. E. (2003) Performance of a hybrid reverse osmosis-constructed wetland treatment system for brackish oil field producedwater.Water Res. 37: 705-713.

[52] Çakmakci M., Kayaalp N. and Koyuncu I. (2008) Desalination of producedwater from oil production fields by membrane processes.Desalination. 222: 176-186.

[53] Barrufet M., Burnett D. and Mareth B. (2005) Modeling and operation of oil removal and desalting oilfield brines with modular units. in SPE Annual Technical Conference and Exhibition, Dallas, Texas, USA, 2005.

[54] Tao F. T., Pilger P. F. and Dyke C. A. (1993) Reducing aqueous boron concentrations with reverse osmosis membranes operating at a high pH. US Patent 5,250,185, 5 October 1993.

[55] Funston R., Ganesh R. and Leong L. Y. (2002) Evaluation of Technical and Economic Feasibility of Treating Oilfield ProducedWater to Create a "New" Water Resource. Available: http://www.kennedyjenks.com/News_Pubs/GWPC2002_Roger_Funston.pdf.

[56] Tsang P. B. and Martin C. J. (2004) Economic evaluation of treating oilfield producedwater for potable use. in Thermal Operations and Heavy Oil Symposium, Bakersfield, USA, 2004.

[57] Doran G. F., Carini F. H., Fruth D. A., Drago J. A. and Leong L. Y. (1997) Evaluation of technologies to treat oil field producedwater to drinking water or reuse quality. in SPE Annual Technical Conference and Exhibition, San Antonio, Texas, USA, 1997.

[58] Liangxiong L., Whitworth T. and Lee R. (2003) Separation of inorganic solutes from oilfield producedwater using a compacted bentonite membrane.Journal of Membrane Science. 217: 215-225.

[59] Kojima S., Okada S., Sasaki T., Oba T., Fujise A. and Kusuyama K. (2011)Reliability Study for Mebrane-Processed water for Injection (WFI).PDA Journal of GMP and Validation in Japan.13: 47-55.

[60] Dallbauman L. and Sirivedhin T. (2005) Reclamation of producedwater for beneficial use.Separation Science and Technology.40: 185-200.

[61] Benko, L. K. (2009) Ceramic membranes for produced water treatment. World oil J. 230 (4). Access: http://www.worldoil.com/April-2009-Ceramic-membranes-for-producedwater-treatment.html

[62] Guerra K., Dahm, K. Dundorf, S. (2011) Oil and Gas Produced Water Management and Beneficial Use in the Western United States. U.S. Department of the Interior, Bureau of Reclamation. 